\title{
Chip Formation and Machinability of Nickel-Base Superalloys
}

\author{
Carsten Siemers ${ }^{1, a}$, Badya Zahra ${ }^{1, b}$, Dawid Ksiezyk ${ }^{2, \mathrm{c}}$, Pawel Rokicki, ${ }^{3, \mathrm{~d}}$, \\ Zdenek Spotz ${ }^{3, \mathrm{e}}$, Lenka Fusova ${ }^{3, \mathrm{f}}$, Joachim Rösler ${ }^{1, \mathrm{~g}}$ and Karel Saksl ${ }^{3, \mathrm{~h}^{\prime}}$ \\ ${ }^{1}$ Institute of Materials Science, Technische Universität Braunschweig, Langer Kamp 8, 38106 \\ Braunschweig, Germany \\ ${ }^{2}$ Institute for Production Technology, Technische Universität Braunschweig, Langer Kamp 19b, \\ Braunschweig, Germany \\ ${ }^{3}$ Slovak Academy of Sciences, Institute of Materials Research, Watsonova 47, 04001 Kosice, \\ Slovakia \\ ac.siemers@tu-bs.de, bb.zahra@tu-bs.de, cd.ksiezyk@iwf.tu-bs.de, dpawel.rokicki@gmail.com, \\ eme2dd@seznam.cz, 'ffusova@imr.saske.sk, ${ }^{\mathrm{g} j . r o e s l e r @ t u-b s . d e, ~}{ }^{\mathrm{h}} \mathrm{ksaksl@imr.saske.sk}$
}

Key words: Nickel-base superalloys, Alloy 625, chip formation, machinability, alloy modification, free-machining nickel-base alloy

\begin{abstract}
Nickel-base superalloys like Alloy 625 are widely used in power generation applications and in the oil and gas industry due to their unique properties especially at elevated temperatures. The chip formation process of Alloy 625 is not yet well understood. Therefore, the cutting process of this alloy has been studied in detail by means of orthogonal cutting experiments at conventional cutting speeds and in the high-speed cutting regime. Alloy 625 shows a cutting parameter dependent change in the chip formation process from continuous to segmented chips. Silver has been added to Alloy 625 to improve the machinability. During machining of these modified alloys short breaking chips develop so that cutting processes are eased and can be automated.
\end{abstract}

\section{Introduction}

Nickel-base superalloys are normally used in high-temperature applications whenever steels (due to drop in mechanical properties at elevated temperature) or titanium alloys (due to insufficient oxidation resistance above $550^{\circ} \mathrm{C}$ ) cannot be applied anymore. In aerospace engine applications or in stationary gas turbines, excellent mechanical properties are needed at temperatures above $600^{\circ} \mathrm{C}$ in combination with corrosion and oxidation resistance [1].

Nickel-base superalloys normally contain several alloying elements. The addition of aluminium (Al) leads to the formation of thermally stable precipitations of $\gamma^{\prime}$-phase $\left(\mathrm{Ni}_{3} \mathrm{Al}\right)$ in the matrix material $(\gamma$-phase). If niobium $(\mathrm{Nb})$ is present in the alloys, metastable $\gamma$ ''-phase precipitations $\left(\mathrm{Ni}_{3} \mathrm{Nb}\right)$ form also increasing the strength of the alloy. On the other hand, $\gamma$ ' '-phase transforms to the stable $\delta$-phase if long-term heat treatments are performed between $700^{\circ} \mathrm{C}$ and $850^{\circ} \mathrm{C}$ causing loss in strengthening [2]. In addition, aluminium ( $\mathrm{Al}$ ), chromium $(\mathrm{Cr})$ and molybdenum (Mo) as alloying elements lead to excellent corrosion and oxidation resistance. Due to its excellent corrosion resistance, the class of Ni-Cr-Mo alloys like Alloy 625 (chemical composition in wt $\%$ Ni: bal, Cr: $20-23 \%$; Fe: $<5 \%$; Si: $<0,5 \%$; Mn $<0.5 \%$; Mo $8-10 \%$; Ti $<0.4 \%$; Co $<1 \%$; $\mathrm{Nb}+\mathrm{Ta}: 3.15-$ $4.15 \% ; \mathrm{Al}<0.4 \%$ ) is therefore not only applied in stationary gas turbines as sealing material or for exhaust systems, but is also used in low-temperature applications in the oil or gas industry wherever the corrosion resistance of steels in liquid media is not sufficient anymore [3].

During the component manufacturing of related Alloy 625 products in any application, up to $50 \%$ of forged semi-finished parts have to be removed by different machining operations [4]. If the finished parts were assembled from prefabricated components, welding or brazing would be involved, which might cause microstructural transformations leading to increased notch-sensitivity or to the formation of $\delta$-phase. Therefore machining from a single workpiece is preferred. Due to the high strength and toughness of Alloy 625 only low cutting speeds can be applied during metal 
cutting operations as otherwise poor surface quality and enhanced tool wear is observed [5]. In addition, the cutting process has to be interrupted as often as it is necessary to remove the long chips from the process zone. Automatisation especially of turning or drilling operations is therefore impossible. The following suggestions are given for machining of Alloy 625: turning operations, cutting speed $<80 \mathrm{~m} / \mathrm{min}$, drilling operations, cutting speed between $3 \mathrm{~m} / \mathrm{min}$ and $5 \mathrm{~m} / \mathrm{min}$ [6].

The machinability of Alloy 625 can only be improved if the cutting process is fully understood. Therefore, in the current study, orthogonal cutting experiments have been performed and the resulting chips have been analysed by optical microscopy and scanning electron microscopy. Based on these results, alloy modifications based on Alloy 625 have been developed and investigated.

\section{Chip Formation of Alloy 625}

Experimental Setup. Orthogonal cutting experiments have been carried out on a computer numerically controlled (CNC) lathe on a sectioned sample. The main goal of these cutting experiments was to determine a possible cutting parameter dependent change in the chip formation mechanism from continuous chips to segmented chips [5]. Therefore, the cutting conditions (cutting speed $\left(\mathrm{v}_{\mathrm{c}}\right)$ and cutting depth $\left(\mathrm{a}_{\mathrm{p}}\right)$ have been varied in a wide range. No cooling fluids have been used to avoid contamination of the chips [7].

For the sample production, round bars of Alloy 625 of diameter $78 \mathrm{~mm}$ have been sectioned by relief grooving, the remaining rings had a width of $5 \mathrm{~mm}$. During the cutting operation, the tool was moved in radial direction (towards the centre of rotation) to remove parts of the rings so that an orthogonal cut has been performed. As the width of the cutting blade was larger than the width of cut, the deformation of the chip's material was not hindered at the free surface.

A tool holder carrying a standard SECO CNMA 120408 (TK 2000) TiN-coated cutting blade with a rake angle of $0^{\circ}$ has been used for the experiments. Cutting speeds $\left(\mathrm{v}_{\mathrm{c}}\right)$ between $20 \mathrm{~m} / \mathrm{min}$ and $300 \mathrm{~m} / \mathrm{min}$ and three different cutting depths $\left(a_{p}\right)$, namely $0.05 \mathrm{~mm}, 0.1 \mathrm{~mm}$ and $0.15 \mathrm{~mm}$, have been applied. Hence, the experiments have been carried out in the conventional cutting regime $\left(20 \mathrm{~m} / \mathrm{min} \leq \mathrm{v}_{\mathrm{c}} \leq 80 \mathrm{~m} / \mathrm{min}\right)$ as well as in the high-speed cutting regime $\left(80 \mathrm{~m} / \mathrm{min} \leq \mathrm{v}_{\mathrm{c}} \leq\right.$ $300 \mathrm{~m} / \mathrm{min}$ ). According to the workpiece geometry, the width of cut was fixed to $5 \mathrm{~mm}$. The length of cut was about $500 \mathrm{~mm}$ (approximately two rounds of cut) as tool wear would lead to a change in the tool's geometry already after a short distance of cut, especially if extreme cutting conditions $\left(\mathrm{v}_{\mathrm{c}}=300 \mathrm{~m} / \mathrm{min}, \mathrm{a}_{\mathrm{p}}=0.15 \mathrm{~mm}\right)$ were applied. A new tool has been used for every cutting operation.

Chip Formation Process. Alloy 625 shows a cutting parameter dependent change in the chip formation process, see Fig. 1.
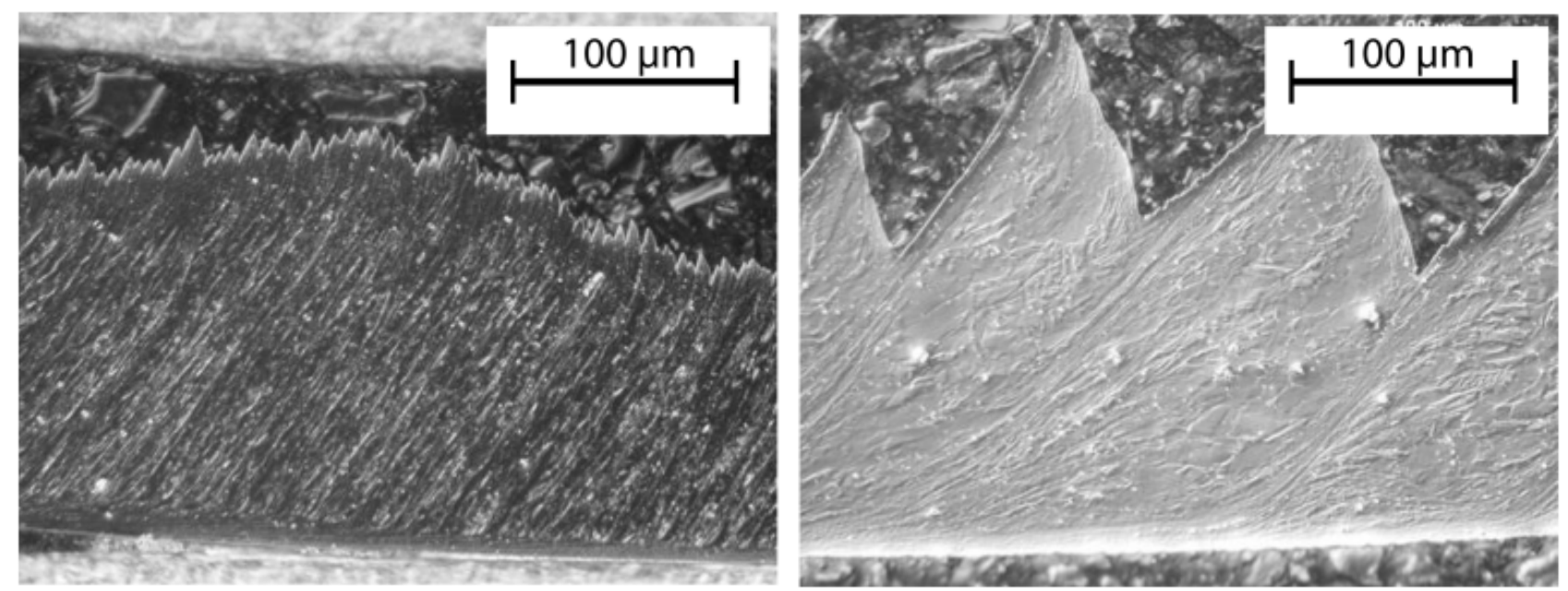

Fig. 1: Chips of Alloy 625 from orthogonal cutting experiments. Left: continuous chip, $\mathrm{v}_{\mathrm{c}}=20 \mathrm{~m} / \mathrm{min}, \mathrm{a}_{\mathrm{p}}=0.1 \mathrm{~mm}$; right: segmented chip, $\mathrm{v}_{\mathrm{c}}=300 \mathrm{~m} / \mathrm{min}, \mathrm{a}_{\mathrm{p}}=0.15 \mathrm{~mm}$. 


\section{Alloy Modification}

In order to improve the machinability of Alloy 625, $0.5 \mathrm{wt} \%$ (named Alloy $625 \mathrm{FM}-05$ ), $1 \mathrm{wt} \%$ (named Alloy $625 \mathrm{FM}-1$ ) and $2 \mathrm{wt} \%$ (named Alloy $625 \mathrm{FM}-2$ ) of silver (Ag) have been added. As starting materials for the alloy production, the commercially available material Alloy 625 [8] and pure Ag (purity 99.99\%) have been used. The standard Alloy 625 (named Alloy $625 \mathrm{R}$ ) has been investigated as a reference material.

All alloys (including Alloy $625 \mathrm{R}$ ) were fabricated by plasma arc melting in a laboratory PBCHM (plasma beam cold hearth melting) furnace of a capacity of about $500 \mathrm{~g}$. After melting, turning and two times remelting (to ensure sufficient homogeneity of the alloys) the material has been poured into a water cooled copper crucible (fast cooling). The resulting bars of diameter $13 \mathrm{~mm}$ and length about $90 \mathrm{~mm}$ have been investigated either directly in the as-cast state or have been subjected to two different heat treatments, namely (1) $800^{\circ} \mathrm{C} / 4 \mathrm{~h} /$ air cool, the "stress relief anneal" and (2) $1038^{\circ} \mathrm{C} / 1 \mathrm{~h} /$ water quench, the "low temperature solution anneal".

According to the Ni-Ag binary phase diagram, the solvability of silver in nickel is negligible at room temperature, whereas complete solvability exists in the liquid state. During the solidification of the Ag-containing alloys, the nickel matrix crystallises first and the remaining liquid phase is enriched in Ag. Finally, Ag-rich particles should form in the interdendritic areas and on the grain boundaries.

Microstructure and Phase Analyses. The microstructure of Alloy 625 FM-2 is shown in Fig. 2.
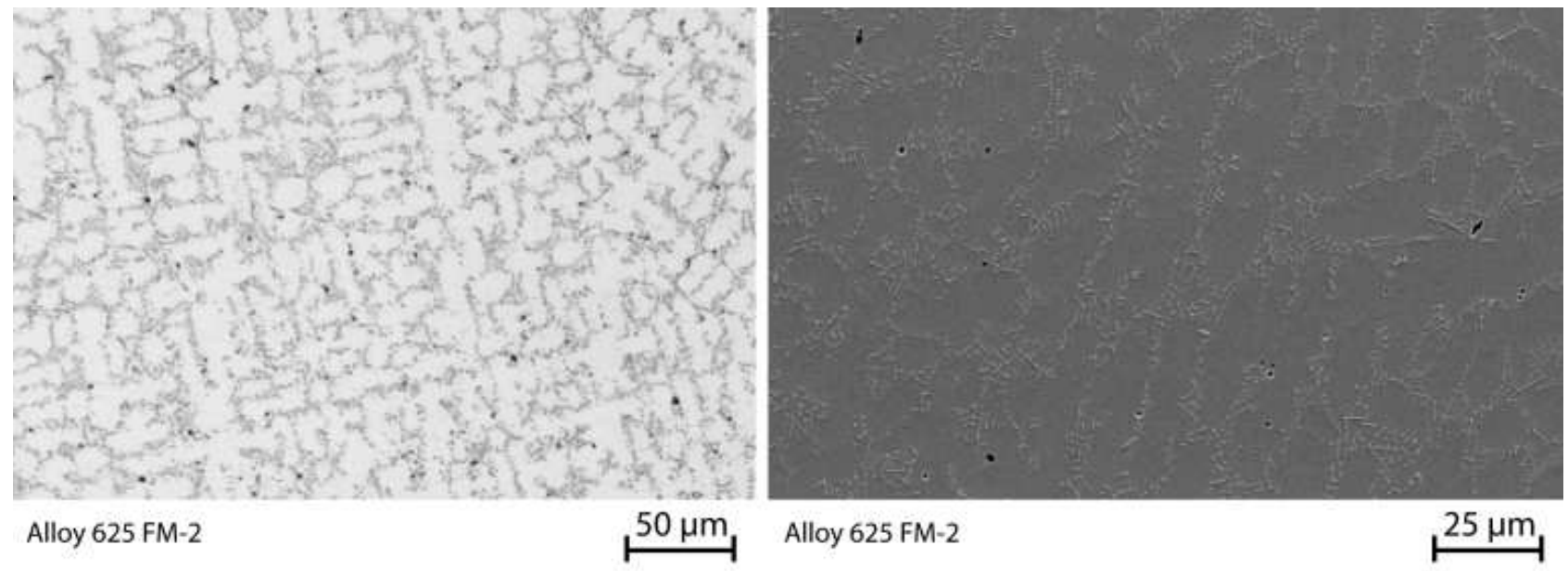

Alloy $625 \mathrm{FM}-2$

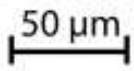

Alloy $625 \mathrm{FM}-2$

Fig. 2: Typical microstructure of Alloy 625 containing $2 \mathrm{wt} \%$ Ag subjected to the stress relief heat
treatment. Left: Optical microscopic image; besides the nickel matrix (bright), $\delta$-phase is observed (grey); in addition, Ag-rich particles (black spots) are visible. Right: SEM-image of Alloy 625 FM-

2 , the Ag particles are homogeneously distributed in the matrix material.

The microstructure of the silver containing alloys consists of a nickel matrix containing $\gamma^{\prime}, \gamma^{\prime \prime}$ or $\delta$-phase (depending on the heat treatment performed) and additional particles having a globular shape, see Fig. 2, left. The particle size lies between $1 \mu \mathrm{m}$ and $10 \mu \mathrm{m}$ and is in the same order as the shear band width, see Fig. 2, right. The particles are homogenously distributed in the alloy.

As the nature of the particles is of crucial importance for improved machinability they have been investigated in hard X-ray experiments as information from the bulk material is needed [9]. The particles in all Ag-containing alloys consist of elementary silver; the related lattice parameter of the fcc Ag cell has been measured to $\mathrm{a} \approx 0.4085 \mathrm{~nm}$ (three peaks). Intermetallic compounds have neither been found in the as-cast state nor after the several heat treatments performed. 
Machinability and Chip Formation. The machinability of the Ag-containing alloys has been investigated in straight turning experiments. The cutting speed has been varied between $20 \mathrm{~m} / \mathrm{min}$ (continuous chip formation in the standard material) and $80 \mathrm{~m} / \mathrm{min}$ (segmented chip formation in the standard material). Two cutting depth of $0.5 \mathrm{~mm}$ and $1 \mathrm{~mm}$ were used and the feed rate has been fixed to $0.1 \mathrm{~mm} / \mathrm{rd}$. The rake angle has been varied from $0^{\circ}$ (as used in the orthogonal cutting experiments) to $25^{\circ}$ (standard in metal cutting of Alloy 625 in industry).

During the turning of the standard alloy Alloy $625 \mathrm{R}$, long chips (length of more than $1000 \mathrm{~mm}$ ) have been produced independent of the cutting conditions applied. The Ag-containing alloys on the other hand formed short breaking or fragmented chips if a minimum cutting speed of $60 \mathrm{~m} / \mathrm{min}$ (in case of $0.5 \mathrm{wt} \% \mathrm{Ag}$ ) or $40 \mathrm{~m} / \mathrm{min}$ (in case of $1 \mathrm{wt} \% \mathrm{Ag}$ or $2 \mathrm{wt} \% \mathrm{Ag}$ ) has been used, see Fig. 3. All chips could be manually fragmented.

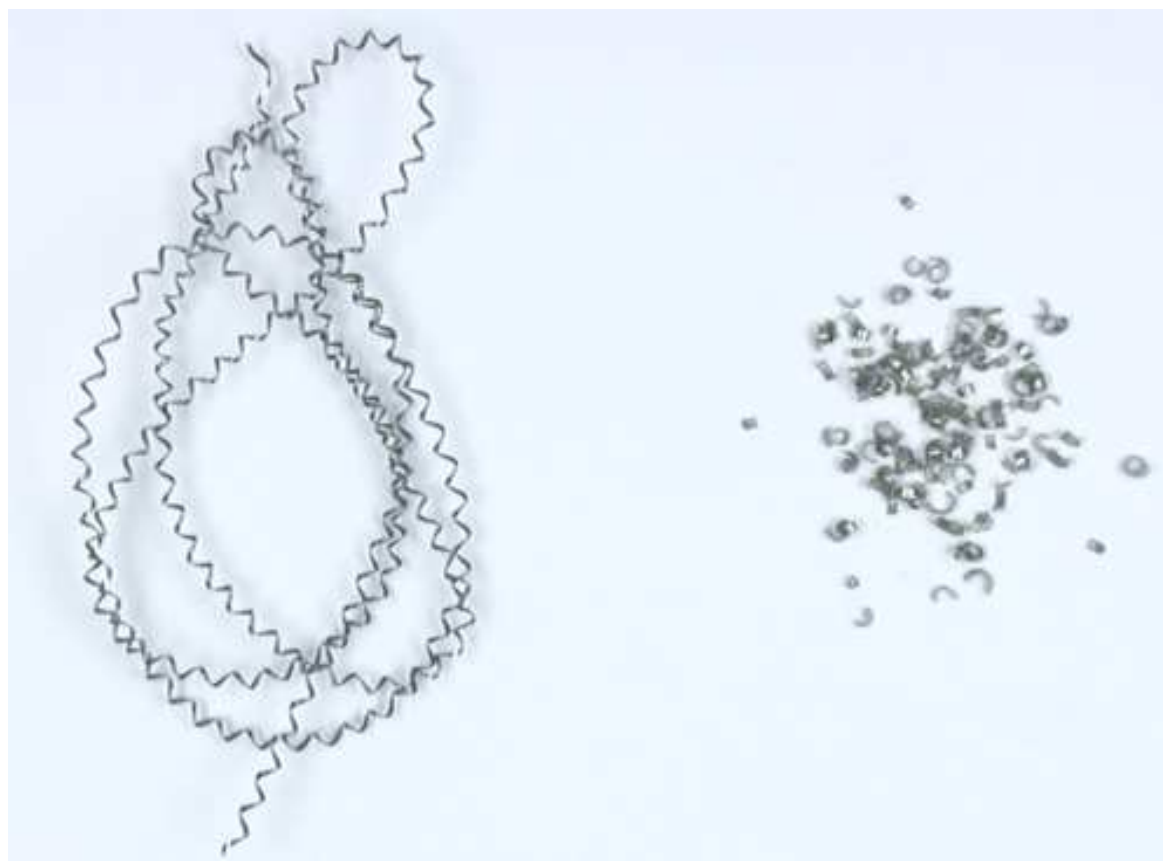

Fig. 3: Chips of Alloy $625 \mathrm{R}$ (left, long chips) and Alloy 625 FM-2 (right, fragmented chips) in the stress relief annealed state, $\mathrm{v}_{\mathrm{c}}: 60 \mathrm{~m} / \mathrm{min}, \mathrm{a}_{\mathrm{p}}: 1 \mathrm{~mm}$, feed rate: $0.1 \mathrm{~mm} / \mathrm{rd}$, rake angle $0^{\circ}$.

The shortest chips were produced while machining Alloy 625 FM-2. In any case, the cutting speed needed for the formation of short breaking chips was lower than the cutting speed used in industrial machining. Therefore, the beneficial effects of the modified alloys (i.e. automatisation of cutting operations) could be exploited during industrial component manufacturing. In addition, it can be expected that tool wear decreases due to the shorter contact length between rake face of the tool and chip leading to lower temperatures at the tool tip.

Detailed results of the cutting experiments for a cutting depth of $0.5 \mathrm{~mm}$ are shown in table 1 . These observations can be explained as follows: during the segmented chip formation the deformation is concentrated in the primary shear zone leading to a local raise in temperature. During further progress of the tool, the deformation localises, a shear band is formed and the temperature is significantly raised. If a silver particle (melting point of $\mathrm{Ag}$ is about $960^{\circ} \mathrm{C}$ ) is located in the shear band it will drastically soften or even melt due to the increase in temperature. The adhesion between the segments would be diminished and the chips separated in the shear bands. Detailed analyses of the chip fragments showed that the chips where separated in the shear zones. 
Table 1: Chip length of the different Alloys $625 \mathrm{FM}-\mathrm{X}$ compared to Alloy $625 \mathrm{R}, \mathrm{a}_{\mathrm{p}}=0.5 \mathrm{~mm}$.

\begin{tabular}{|c|c|c|c|c|}
\hline alloy & \multirow[t]{2}{*}{ Alloy $625 \mathrm{R}$} & \multirow[t]{2}{*}{ Alloy 625 FM-05 } & \multirow[t]{2}{*}{ Alloy 625 FM-1 } & \multirow[t]{2}{*}{ Alloy 625 FM-2 } \\
\hline state & & & & \\
\hline as-cast & long chips & $\begin{array}{l}\text { short breaking } \\
\mathrm{v}_{\mathrm{c}} \geq 60 \mathrm{~m} / \mathrm{min}\end{array}$ & $\begin{array}{l}\text { short breaking } \\
\mathrm{v}_{\mathrm{c}} \geq 40 \mathrm{~m} / \mathrm{min}\end{array}$ & $\begin{array}{l}\text { short breaking } \\
\mathrm{v}_{\mathrm{c}} \geq 40 \mathrm{~m} / \mathrm{min}\end{array}$ \\
\hline stress relief & long chips & $\begin{array}{l}\text { short breaking } \\
\mathrm{v}_{\mathrm{c}} \geq 60 \mathrm{~m} / \mathrm{min}\end{array}$ & $\begin{array}{l}\text { short breaking } \\
\mathrm{v}_{\mathrm{c}} \geq 40 \mathrm{~m} / \mathrm{min} \\
\text { fragmented } \\
\mathrm{v}_{\mathrm{c}} \geq 60 \mathrm{~m} / \mathrm{min}\end{array}$ & $\begin{array}{c}\text { short breaking } \\
\text { from } 40 \mathrm{~m} / \mathrm{min} \\
\text { fragmented } \\
\mathrm{v}_{\mathrm{c}} \geq 60 \mathrm{~m} / \mathrm{min}\end{array}$ \\
\hline solution treated & long chips & $\begin{array}{c}\text { short breaking } \\
\mathrm{v}_{\mathrm{c}} \geq 40 \mathrm{~m} / \mathrm{min} \\
\text { fragmented } \\
\mathrm{v}_{\mathrm{c}} \geq 80 \mathrm{~m} / \mathrm{min}\end{array}$ & $\begin{array}{l}\text { short breaking } \\
\mathrm{v}_{\mathrm{c}} \geq 40 \mathrm{~m} / \mathrm{min} \\
\text { fragmented } \\
\mathrm{v}_{\mathrm{c}} \geq 60 \mathrm{~m} / \mathrm{min}\end{array}$ & $\begin{array}{c}\text { short breaking } \\
\mathrm{v}_{\mathrm{c}} \geq 40 \mathrm{~m} / \mathrm{min} \\
\text { fragmented } \\
\mathrm{v}_{\mathrm{c}} \geq 60 \mathrm{~m} / \mathrm{min}\end{array}$ \\
\hline
\end{tabular}

Besides the fact that automatisation of cutting operations would be possible if short breaking chips form, the passive forces during metal cutting should decrease (due to the relatively small samples, cutting forces could not be measured). This should lead to improved surface quality of the finished workpiece. The surface roughness of all specimens has therefore been investigated after the final cutting step; the results (values for $\mathrm{R}_{\mathrm{z}}$ and $\mathrm{R}_{\mathrm{a}}$ ) are shown in table 2 .

Table 2: Surface quality of the different modified alloys Alloy 625 FM-X compared to Alloy $625 \mathrm{R}$ after the final cutting step in the turning experiments.

\begin{tabular}{|c|c|c|c|c|}
\hline alloy & \multirow[t]{2}{*}{ Alloy $625 \mathrm{R}$} & \multirow[t]{2}{*}{ Alloy 625 FM-05 } & \multirow[t]{2}{*}{ Alloy 625 FM-1 } & \multirow[t]{2}{*}{ Alloy 625 FM-2 } \\
\hline state & & & & \\
\hline as-cast & $\begin{array}{l}\mathrm{R}_{\mathrm{z}} 5.30 \mu \mathrm{m} \\
\mathrm{R}_{\mathrm{a}} 0.78 \mu \mathrm{m}\end{array}$ & $\begin{array}{l}\mathrm{R}_{\mathrm{z}} 4.48 \mu \mathrm{m} \\
\mathrm{R}_{\mathrm{a}} 0.66 \mu \mathrm{m}\end{array}$ & $\begin{array}{l}\mathrm{R}_{\mathrm{z}} 4.10 \mu \mathrm{m} \\
\mathrm{R}_{\mathrm{a}} 0.65 \mu \mathrm{m}\end{array}$ & $\begin{array}{l}\mathrm{R}_{\mathrm{z}} 5.02 \mu \mathrm{m} \\
\mathrm{R}_{\mathrm{a}} 0.76 \mu \mathrm{m}\end{array}$ \\
\hline stress relief & $\begin{array}{l}\mathrm{R}_{\mathrm{z}} 5.63 \mu \mathrm{m} \\
\mathrm{R}_{\mathrm{a}} 0.65 \mu \mathrm{m}\end{array}$ & $\begin{array}{l}\mathrm{R}_{\mathrm{z}} 4.67 \mu \mathrm{m} \\
\mathrm{R}_{\mathrm{a}} 0.81 \mu \mathrm{m}\end{array}$ & $\begin{array}{l}\mathrm{R}_{\mathrm{z}} 4.43 \mu \mathrm{m} \\
\mathrm{R}_{\mathrm{a}} 0.76 \mu \mathrm{m}\end{array}$ & $\begin{array}{l}\mathrm{R}_{\mathrm{z}} 4.93 \mu \mathrm{m} \\
\mathrm{R}_{\mathrm{a}} 0.92 \mu \mathrm{m}\end{array}$ \\
\hline solution treated & $\begin{array}{l}\mathrm{R}_{\mathrm{z}} 5.35 \mu \mathrm{m} \\
\mathrm{R}_{\mathrm{a}} 0.84 \mu \mathrm{m}\end{array}$ & $\begin{array}{l}\mathrm{R}_{\mathrm{z}} 5.18 \mu \mathrm{m} \\
\mathrm{R}_{\mathrm{a}} 0.94 \mu \mathrm{m}\end{array}$ & $\begin{array}{l}\mathrm{R}_{\mathrm{z}} 4.02 \mu \mathrm{m} \\
\mathrm{R}_{\mathrm{a}} 0,65 \mu \mathrm{m}\end{array}$ & $\begin{array}{l}\mathrm{R}_{\mathrm{z}} 4.03 \mu \mathrm{m} \\
\mathrm{R}_{\mathrm{a}} 0.65 \mu \mathrm{m}\end{array}$ \\
\hline
\end{tabular}

As indicated in table 2, the surface quality of the silver containing alloys is slightly improved in all heat treatment states compared to the standard alloy as expected. If similar workpiece quality has to be achieved, the cutting speed could be increased in the Ag-containing alloys.

First tensile tests at room temperature have been carried out indicating that the addition of $\mathrm{Ag}$ to Alloy 625 does not change the strength or ductility significantly but further studies are needed to verify these results. 


\section{Conclusions and Outlook}

During machining of Alloy 625 long chip formation is observed. Addition of homogeneously distributed particles with a comparably low melting point can only effectively promote the formation of short breaking chips if segmented chip formation is observed. As Alloy 625 forms segmented chips already at conventional cutting speeds, the distribution of micrometer-size Ag particles in the nickel matrix leads to the formation of short breaking chips. In addition, the surface quality during turning is improved by the addition of silver. It can be expected that the distribution of particles having a melting point below $1000^{\circ} \mathrm{C}$ will improve the machinability of nickel-base superalloys if segmented chip formation is observed.

Future work will concentrate on the investigation of the complete production chain of the Agcontaining alloys Alloy 625 FM-X. In addition, the microstructure-properties-relationship like temperature-dependent mechanical properties and the corrosion resistance of the new class of freemachining nickel-base superalloys will be studied.

\section{Acknowledgement}

The research leading to these results has received funding from the European Union Seventh Framework Programme (FP7/2007-2013) under grant agreement No. PITN-GA-2008-211536, project MAMINA. Financial support is therefore gratefully acknowledged. The authors thank Mr. M. von Zimmermann and Mr. J. Bednarcik for the assistance during the hard X-ray experiments at beamline BW5, HASYLAB, DESY in Hamburg, Germany.

\section{References}

[1] C.T. Sims, N.S. Stoloff and W.C. Hagel: Superalloys II (Wiley \& Sons, Canada 1987).

[2] R.C. Reed: The Superalloys: Fundamentals and Applications (Cambridge University Press, UK 2008).

[3] M.J. Donarchie and S.J. Donarchie: Superalloys: A Technical Guide (ASM International, USA 2002).

[4] R. Komanduri and T.A. Schroeder: On Shear Instability in Machining a Nickel--Iron Base Superalloy High Speed Machining; New Orleans, Louisiana; USA; 9-14 Dec. 1984, 287-307.

[5] I.A. Choudhury and M.A. El-Baradie, J. Mater. Process. Technol. 77(1-3) (1998), 278-284.

[6] Information on http://www.hightempmetals.com/

[7] E.O. Ezugwu, Int. J. Mach. Tool. Manufact. 45(12-13) (2005), 1353-1367.

[8] M. Durrand-Charre: Microstructure of Superalloys (Gordon and Breach Science Publishers, Netherlands 2003).

[9] R. Bouchard, D. Hupfeld, T. Lippmann, J. Neuefeind, H.B. Neumann, H.F. Poulsen, U. Rütt, T. Schmidt, J.R. Schneider, J. Süssenbach, and M. von Zimmermann, J. Synchrotron Radiat. 5(2) (1998), 90-101. 